\title{
Spectrum of Communicable Diseases in Lesbos Island UNHCR Refugee Camp
}

T. Simonek (Thomas Simonek)', M. Jackulikova (Maria Jackulikova)', A. Topolska (Alex Topolska)1,2, M. Jancovic (Mario Jancovic)', L. Jancovicova (Lucia Janovicova)', L. Slusna (Lenka Slusna)', M. Hardy (Maria Hardy)', M. Valach (Michal Valach)³, M. Sramkova (Maria Sramkova)', M. Popovicova (Maria Popovicova)', D. Barkasi (Daniela Barkasi)', K. Prochazkova (Katarina Prochazkova)', L. Libova (Lubica Libova)', M. Mrazova (Mariana Mrazova)', R. Vlcek (Robert Vlcek)', M. Gulasova (Monika Gulasova)3, J. Otrubova (Jana Otrubova)33, L. Radkova (Libusa Radkova) ${ }^{3}$. A. Murgova (Anna Murgova)3, P. Vansac (Peter Vansac)3, R. Hochman (Rastislav Hochman)3, H. Konosova (Helena Konosova) ${ }^{3}$, M. Katunska (Monika Katunska)³, M. Bakos (Marian Bakos)3), M. Bielova (Maria Bielova)³, F. Sasvary (Ferdinand Sasvary)3), E. Grey (Eva Grey) ${ }^{1,3}$

${ }^{1}$ UNHCR Camp Lesbos Greece, St. Elizabeth University, Bratislava

Original Article Refugee and Migrant Health Programme in Greece, Bosna, Albania.

2 SEUC Antimalnutrition Programme Taizz, Yemen.

${ }^{3}$ St. Lesley College, Nove Zamky, St. Dominic Institute Michalovce, Institute Zilina, and St. Francis Health Center Vlore, Albania.

${ }^{4}$ St. Sarah Institute RV and Malnutrition Post Backi Petrovec, Republic of Serbia.

\section{E-mail address:}

tomas.simonek@gmail.com

\section{Reprint address:}

Thomas Simonek

UNHCR Health Centre

Lesbos Island

Greece

Source: Clinical Social Work and Health Intervention $\quad$ Volume: $10 \quad$ Issue: 4

Pages: $\quad$ Cited references: 4

\section{Reviewers:}

Clauss Muss

I-GAP Zurich, Switzerland

Daria Kimuli

Catholic university of Eastern Africa, Nairobi, Kenya 


\section{Keywords:}

Migrant Health.

\section{Publisher:}

International Society of Applied Preventive Medicine i-gap

CSWHI 2019; 10(4): 57 - 59; DOI: 10.22359/cswhi_10_4_10 @ 2019 Clinical Social Work and Health Intervention

\section{Abstract:}

Introduction: Refugee and Migrant Health Programmes in EU react on Migrant and refugee crisis (1) from middle East armed conflict to EU .The aim of this study was to asess the spectrum of communicable diseases among migrants to UNHCR camp on Lesbos island.

Metods: Open study was performed in 2019 to assess the frequency and proportion of ID among migrants and refugees to Greece.

Results: In 1-6/2019 among 9601 patients, 2138 patients with CD were diagnosed. Respiratory tract ID were in 1335 cases, SSTI in 493, UTI/ STI in 136, GIID in 183 cases. No case of TB was detected, HN only $0,4 \%$.

Conclusion: Despite the fact that one fourth of all patients at refugee camp in Lesbos island had infectious diseases, HIV was exceptional and no case on TB was detected. No outbreaks reported.

\section{Introduction:}

One of emerging issues in EU is still migrant/refugee crisis Refugee and $\mathrm{Mi}$ grant Health Programmes in EU react on Migrant and refugee crisis (1) from middle East armed conflict to EU (2). The aim of this study was to away the spectrum of communicable diseases among migrants to UNHCR camp on Lesbos Island.

\section{Methods:}

Open study was performed in 2019 to assess the frequency and proportion of ID among migrants and refugees to Greece. Occurence of particular diseases was analysed

\section{Results:}

Among 9,601 patients who presented themselves at the OPD Health Centre at
Lesbos UNHCR Camp (about 60\% refugees from Afghanistan, Syria, Sub-saharan Africa and 2238 (23\%) had infectious diseases diagnosis (ID CD). Majority had RTI 1335, followed by SSTI/wounds 493. Surprisingly, only very few cases were $\mathrm{HIV}$ positive $(0,4 \%)$ or had $\mathrm{HBC} / \mathrm{HCV}$. Zero cases of confirmed TB were detected, similarly to data from camps on Greek mainland. Also WHO and UNHCR was reputing few cases of documented TB, HIV or malaria to Greece from Turkey in 2015$2018(1,4)$

\section{Conclusion:}

Despite the fact that one fourth of all patients at refugee camp in Lesbos island had infectious diseases, HIV was exceptional and no case on TB was detected. No outbreaks reported. Low occurence of HIV, $\mathrm{BHC}, \mathrm{HCV}$ is due to prevalence of mus- 
Table 1: Occurence of communicable diseases among refugees in Lesbos Island Camp UNHCR in 1-6/2019

\begin{tabular}{|l|c|}
\hline Total No. of patients & 9601 \\
\hline No. of patients with communicable diseases & $2238(23 \%)$ \\
\hline Respiratory tract infections & 1335 \\
\hline Skin and soft tissue infections / wounds & 493 \\
\hline Gastrointestinal & 183 \\
\hline Urogenital & 136 \\
\hline Rare: chicken pox (32), HIV (4), HCV (1), TBC (0) \\
\hline
\end{tabular}

lim population migrating from Syria and Afghanistan to Greece, and this population usually presents much lower incidence in HIV and other STD than southeast Asia or subsaharan Africa. Minimal occurence of TB is because there is no avaiable screening simple method in migrant and refugee health avaiable overall prevalence in Syria, Iraq and most $\mathrm{ME}$ countries is below 50/100 000. Lane what is lower than in many host countries.

\section{References:}

1. KALAVSKY E, HERDICS G, VALOVA J, SUBRAMANIAN S, BYDZOVSKY J, PALUN M, NADDOUR A, SUVADA J (2018) Emergencies in Migrant and Refugee $\mathrm{He}$ - alth 2015-2018 (Letter) In: Clinical Social Work and Health Intervention, Vol. 9, Issue 3, 2018 pp 56-57.

2. SUBRAMANIAN S, BELOVICOVA M, VANSAC P, PALUN M, BENCA J, OLAH M, MATULNIKOVA L, SRAMKOVA M, CMOREJ P, KRCMERY V, SHAHUM A (2018) Rehabilitation and Nursing homes with Elderly and Homeless Population, Lessons not only for Physiotherapy but also for Epidemiology?, In: Clinical Social Work and Health Intervention, Vol: 9, Issue: 3, 2018 pp. 64-66.

3. WORLD HEALTH ORGANISATION (2017) Operations manual. WHO Geneve, 2017, 155 pp.

4. UNITED NATIONS HIGH COMISSION REFUGEE ANNUAL REPORT (2018) UNHCR New York, 2019, 206 pp. 